\title{
Biochemical and molecular characteristics of Listeria monocytogenes isolates from a prosthetic mitral heart valve-bearing patient's blood cultures
}

\section{Características bioquímicas e moleculares de Listeria monocytogenes isolados de hemoculturas de próteses de válvula mitral}

Ana Paula Rocha da Costa ${ }^{1,3}$, Marinalda Anselmo Vilela ${ }^{2}$, Carina Lucena Mendes-Marques ${ }^{3}$, Alzira Maria Paiva de Almeida $^{3}$, Nilma Cintra Leal ${ }^{3}$

1. Departamento de Ciências Biológicas, Universidade Federal de Pernambuco, Recife, PE, Brasil. 2. Laboratório de Resistência Microbiana, Instituto de Ciências Biológicas, Universidade de Pernambuco, Recife, PE, Brasil. 3. Centro de Pesquisas Aggeu Magalhães, FIOCRUZ-PE, Recife, PE, Brasil.

\begin{abstract}
Background: In Brazil, listeriosis is not a notifiable disease; thus, the incidence of Brazilian cases remains unknown. Listeria monocytogenes is not always included in automated systems, and its detection depends on the high skill level of microbiology laboratory professionals. This paper describes the characteristics of L. monocytogenes isolates fortuitously obtained from an endocarditis case in Recife, PE, Brazil. Methods: Six bacterial isolates obtained from six blood cultures from a 28-year-old male bearing a prosthetic mitral heart valve were analyzed by PCR using primers specific of L. monocytogenes to confirm a presumptive identification, determine the serotype and presence of the virulence genes (inlA, inlB, inlC, inlJ, hly, plcA, actA, prfA) in an attempt to determine the Listeria genotype by PCR-ribotyping. Results: The samples were identified as L. monocytogenes $4 \mathrm{~b}$. All investigated virulence genes were amplified by PCR, and the identity of the amplified segments was confirmed by sequencing. A deletion of 105 base pairs was detected in the actA gene. All of the samples generated the same PCR-ribotype pattern, clustered into a single ribotype, and were considered a single strain. Conclusion: L. monocytogenes infection should be considered in endocarditis differential diagnoses, especially among high-risk groups, due to its high pathogenicity and the environmental ubiquity.
\end{abstract}

Keywords: Listeria. Listeriosis. Listeria monocytogenes. Endocarditis. Virulence.

\section{Resumo}

Introdução: A listeriose não é uma doença de notificação obrigatória no Brasil e relatos de casos clínicos são escassos. Listeria monocytogenes não é rotineiramente incluída nos sistemas automatizados e sua detecção depende da habilidade dos profissionais dos laboratórios de microbiologia. Neste trabalho, descrevemos as características de isolados de L. monocytogenes obtidos de um caso de endocardite em Recife, PE, Brasil. Métodos: Seis isolados de seis hemoculturas obtidas de um paciente de 28 anos, portador de válvula cardíaca mitral protética foram analisados por PCR utilizando primers específicos para confirmar a identificação, determinar o sorotipo e a presença DOS genes de virulência (inlA, inlB, inlC, inlJ, hly, plcA, actA, prfA) e para determinar o genótipo dos isolados por PCR-ribotipagem. Resultados: As amostras foram identificadas como L. monocytogenes 4b. Todos os genes de virulência investigados foram amplificados, e a identidade dos segmentos foi confirmada por sequenciamento. Uma deleção de 105 pares de bases foi detectada no gene actA. Todas as amostras revelaram padrão de amplificação similar por PCR-ribotipagem e foram consideradas uma única estirpe. Conclusão: Infecção por L. monocytogenes deve ser considerada em diagnósticos diferenciais de endocardite, especialmente entre os grupos de alto risco, devido à sua alta patogenicidade e ubiquidade ambiental.

Palavras-chave: Listeria. Listeriose. Listeria monocytogenes. Endocardite. Virulência.

\section{BACKGROUND}

Listeria monocytogenes is a rod-shaped gram-positive facultative intracellular pathogen that causes the disease so called listeriosis. It primarily affects pregnant women, newborns and immunocompromised adults, causing sepsis, abortion and infection of the central nervous system and resulting in high morbidity and mortality ${ }^{1}$. Out of the 13 recognized $L$. monocytogenes serotypes, three $(1 / 2 a$, $1 / 2 b$ and $4 b)$ appear to be more pathogenic; they are epidemiologically associated with the most serious cases of human listeriosis².

In general, cardiovascular diseases, such as endocarditis and pericarditis, are associated with a poor prognosis and high mortality ${ }^{3,4,5}$. Endocarditis caused by L. monocytogenes infection often occurs in patients with defective or prosthetic heart valves, especially aortic and mitral valves ${ }^{6,7}$. Mortality

Correspondence: nilma@cpqam.fiocruz.br

Ethical issues: This work has not an ethical component. The bacteriological samples derived from spontaneous demand from the hospital microbiology laboratory and the patient's identity were confidentially maintained. Competing interest: Authors declare that they have no competing interest. Received 29 May 2013; Revised 19 Jul 2013; Accepted 24 Jul 2013. 
occurs in $100 \%$ of untreated cases; however, appropriate treatment reduces this rate to $20-30 \%$. This mortality rate is still higher than for endocarditis caused by another bacteria, which is typically $14 \%$ lethal ${ }^{4}$. L. monocytogenes endocarditis is clinically diagnosed by symptoms associated with bacteremia, and treatment of infections is usually accomplished through the administration of antibiotics, often ampicillin and an aminoglycoside ${ }^{3}$. Early identification of $L$. monocytogenes in endocarditis cases and the determination of its antimicrobial sensitivity are crucial for the treatment of affected patients. However, Listeria is seldom suspected as the causative agent of endocarditis, and patient treatment is typically tailored for bacteria that are more frequently involved in endocarditis such as Staphylococcus aureus, Streptococcus viridans, Enterococcus and coagulase negative Staphylococcus $(\mathrm{CoNS})^{8}$. Therefore, the establishment of appropriate treatments may be delayed, aggravating the patient's condition and possibly leading to death as a result of the high pathogenicity of $L$. monocytogenes ${ }^{9}$.

This study analyzed six L. monocytogenes cultures as obtained from a prosthetic mitral heart valve-bearing patient who presented it at an emergency cardiology facility. The presumptive Listeria identification was confirmed by PCR at the genus, species and serotype levels. The genomic profile of the organism was analyzed by PCR-ribotyping, Listeria virulence genes involved in the infection pathway of the main host cells were detected, and the antimicrobial susceptibility of the strains was assessed.

\section{METHODS}

Bacteria isolation, presumptive identification and antimicrobial susceptibility assessment

Six blood cultures were obtained from a 28 -year-old male bearing a bovine pericardial mitral heart valve who presented himself in a cardiology emergency facility in Recife, PE, Brazil. Following clinical evaluation, three blood cultures were collected at 30-minute intervals; however, endocarditis or Listeria infection was not suspected, and the patient was released before the blood culture results were completed. Four days later, the patient entered the intensive care unit after his condition had deteriorated. A second series of blood cultures was collected, and the patient was successfully diagnosed and treated, resulting in a full recovery.

The bacterial growth after 24 hours of incubation was initially identified as Listeria spp. by routine screening using standard bacteriological tests (colony morphology on blood agar plates, Gram staining and motility in semisolid medium $)^{10}$. Antimicrobial susceptibility was determined by disk diffusion on agar plates according to CLSI guidelines for Staphylococcus spp. ${ }^{11}$ and Soussy et al. $(1994)^{12}$ for ampicillin and vancomycin.
Four reference strains from the Collection of the Pasteur Institute (CLIP), the Centers for Disease Control (CDC), and the American Type Culture Collection were used: CLIP12612 (L. innoccua, negative control), CDC F4561 (L. monocytogenes 1/2a), CDC F4976 (L. monocytogenes 1/2b), and ATCC 19115 (L. monocytogenes 4b, positive control) were accounted for.

\section{DNA extraction}

DNA samples were extracted following a protocol based on Ausubel et al.13, with minor modifications. Briefly, $1 \mathrm{ml}$ of each bacterial culture in brain heart infusion broth (BHI, Biobras) was centrifuged for 10 minutes at $14,000 \mathrm{rpm}$, the resulting pellet was washed with $500 \mu \mathrm{L}$ of Tris:EDTA (10:1), and $10 \mu \mathrm{L}$ of $1 \%$ lysozyme and $10 \mu \mathrm{L}$ of $0.5 \%$ Proteinase $\mathrm{K}$ were added. The samples were incubated at $60^{\circ} \mathrm{C}$ for 20 minutes, then $100 \mu \mathrm{L}$ of STE (2.5\% SDS, 0.25 M EDTA, $10 \mathrm{mM}$ Tris $\mathrm{pH} 8.0$ ) was added. The samples were then incubated at $60^{\circ} \mathrm{C}$ for 15 minutes, at room temperature for 5 minutes and in an ice bath for 5 minutes. Next, 130 $\mu \mathrm{L}$ of $7.5 \mathrm{M}$ sodium acetate was added, and the samples were re-incubated in an ice bath for 15 minutes and centrifuged for 3 minutes at 14,000 rpm. At this point, 700 $\mu \mathrm{L}$ of the supernatant was transferred to a new tube, 420 $\mu \mathrm{L}$ of isopropanol was added, and the samples were then incubated at $-80^{\circ} \mathrm{C}$ for 30 minutes and centrifuged at 14,000 rpm for 10 minutes. The supernatant was discarded, and the pellet DNA was vacuum dried and resuspended in $10 \mu \mathrm{L}$ of $0.02 \%$ RNAse. DNA yield was quantified by comparison with known amounts of $\lambda$ HindIII DNA (Sigma).

\section{PCR identification: genus, species and serotyping}

To confirm the identification of the culture, specific primers were used in PCR reactions for amplification of the 235 rRNA gene from the Listeria genus14 and Imo 2243 from L. monocytogenes species15. The serotype was assessed using primers specifically directed to genes from the three most pathogenic serotypes: Imo 0737 for 1/2a15, gltB for $1 / 2 b 16$ and ORF 2110 for $4 b 17$. The reaction mixtures were prepared in $25 \mathrm{~mL}$ volume and included $20 \mathrm{ng}$ of genomic DNA, $50 \mathrm{mM} \mathrm{KCl}, 10 \mathrm{mM}$ TrisHCl (pH 8.0), $200 \mathrm{mM}$ dNTP (Invitrogen), $15 \mathrm{mM} \mathrm{MgCl} 2,20 \mathrm{pM}$ of each primer and $1 \mathrm{U}$ of Taq DNA polymerase (Promega). Amplifications were performed in a Biometra thermocycler programmed for 30 cycles of $1 \mathrm{~min}$ at $92^{\circ} \mathrm{C}, 1 \mathrm{~min}$ at $55^{\circ} \mathrm{C}$ and $1 \mathrm{~min}$ at $72^{\circ} \mathrm{C}$ followed by a $7 \mathrm{~min}$ final extension at $72^{\circ} \mathrm{C}$. As a negative control, a tube containing all reagents but genomic DNA was used in each reaction.

\section{Detection of virulence genes}

The presence of virulence genes involved in the three stages of infection was assessed by PCR under the conditions 
described above. Specific primers were used to detect $\operatorname{in} / \mathrm{A}^{18}$, in/ $\mathrm{B}^{19}$, in $/ \mathrm{C}^{20}$ and $i n / \mathrm{J}^{20}$, which are involved in host cell adhesion and invasion; $h / y^{14}$ and $p / c A^{21}$, which are involved in vacuole escape; $\operatorname{act}^{22}$, which is involved in intracellular propagation; and $\operatorname{prfA^{21}}$, which acts as a virulence gene regulator.

Each amplified gene segment was purified and sequenced in an automated ABI3100 sequencer (Applied Biosystems, USA). The consensus sequence for each gene was compared with published sequences available in GenBank (http:// www.ncbi.nlm.nih.gov) using the Basic Local Alignment Tool (BLASTn). Multiple alignments were performed by $\mathrm{Mega}^{423}$.

\section{PCR-ribotyping}

Ribotyping was performed by PCR using specific primers for amplification of the 16S-23S rDNA intergenic spacer region as described 24.

\section{RESULTS}

\section{Antimicrobial susceptibility}

All samples revealed sensitivity to ampicillin, cephalothin, ciprofloxacin, chloramphenicol, erythromycin, gentamicin, penicillin, rifampin, tetracycline, trimethoprim/ sulfamethoxazole and vancomycin and resistance to cefoxitin by agar disk diffusion.

\section{Determination of the genus, species and serotype by PCR}

Segments of the expected size for the 23S rRNA gene specific to the Listeria genus (239 base pairs = bp), the Imo2234 gene specific to $L$. monocytogenes species ( $420 \mathrm{bp}$ ) and the ORF2110 gene specific to serotype $4 \mathrm{~b}$ (597 bp) were amplified in all samples (data not shown), and the samples were thus determined to be $L$. monocytogenes serotype $4 \mathrm{~b}$. Imo 0737 for $1 / 2$ a and $g / t B$ for $1 / 2 b$ did not amplify.

\section{Virulence genes}

Segments of the expected size were amplified in all samples for the in/A, in/B, in/C and inlJ genes, which are involved in the bacterium adhesion and host cells invasion; the hly and p/cA genes, which are involved in vacuole escape; and the prfA gene, which regulates virulence genes, (data not shown). Comparisons of the amplified segment sequences with published sequences revealed 98 to $100 \%$ identity (data not shown).

A 432 bp segment was detected instead of the expected 537 bp segment, indicating a 105 bp deletion. This amplicon was present in all samples for the actA gene, which is involved in the ability to spread cell-to-cell (Figure 1).

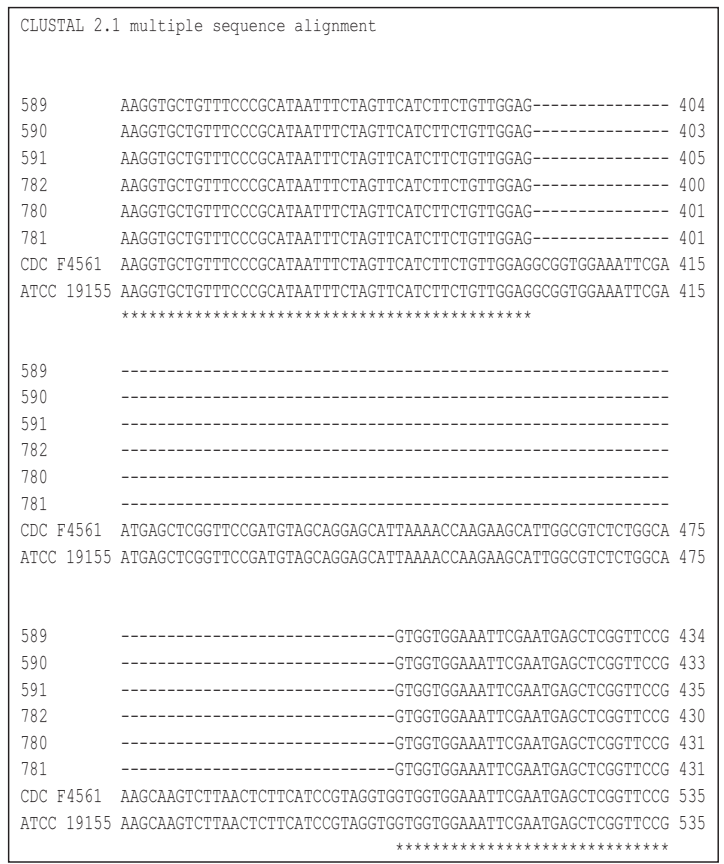

Figure 1. Multiple alignments of partial sequences showing the 105 bp deletion in the actA gene in samples from blood cultures compared with reference strain sequences.

\section{PCR-ribotyping}

All samples generated a similar amplification pattern of the 16S-23S rDNA intergenic spacer region and therefore clustered into the same ribotype. Control serotypes $1 / 2 \mathrm{a}$ and $1 / 2$ b displayed a similar amplification pattern, clustering into the same ribotype (named R1), while serotype $4 \mathrm{~b}$ generated a different amplification pattern and therefore clustered in a separate ribotype (named R2). The six blood culture samples clustered into ribotype 2 (Figure 2).

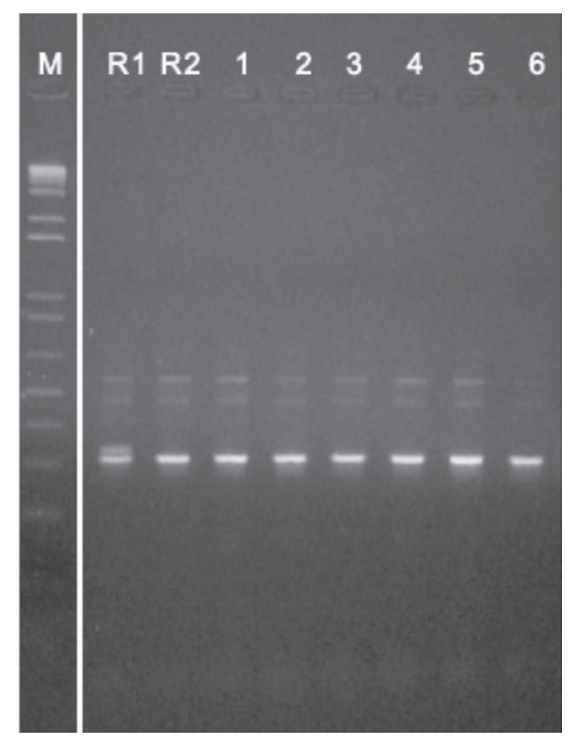

Figure 2. PCR ribotyping profile. Lines: M: $100 \mathrm{bp}$ Molecular marker; R1: Listeria monocytogenes ATCC 19115, serotype 4b; R2: Listeria monocytogenes CDC F4976, serotype 1/2b; 1-6: samples from the study. 


\section{DISCUSSION}

L. monocytogenes can be misidentified by gram-staindetermined morphology as Corynebacterium spp, which is often regarded as a contaminant, especially when the colonies grown from the clinical sample are scarce. In our region, L. monocytogenes is not always included in automated systems and is not often an expected cause of infection because of its low clinical frequency. Therefore, its detection depends on a high level of skill among microbiology laboratory professionals. In Brazil, listeriosis is not a notifiable disease, so the number of Brazilian cases remains unknown ${ }^{25}$. However, the severity of this lifethreatening disease demands rapid treatment to avoid a fatal outcome.

Most clinical L. monocytogenes isolates are susceptible to a wide range of antibiotics ${ }^{26,27}$; however, resistance to chloramphenicol, erythromycin, streptomycin, tetracycline, vancomycin and trimethroprim has been reported ${ }^{28}$. In our region, the various automated identification systems widely employed in clinical microbiology laboratories, although easy and quick, they are not always programmed for lowfrequency organisms like $L$. monocytogenes. The need for accurate antimicrobial susceptibility determination of the microorganisms from clinical material is crucial to avoid ineffective drug use, which can slow the treatment process, aggravate the patient's clinical condition, and possibly lead to a fatal outcome. In this study, antimicrobial susceptibility tests were carried out through disk diffusion on agar, and the cultures were resistant only to cefoxitin.

The six cultures were classified as serotype $4 b$, the most frequent causative agent of human listeriosis, and clustered into the same ribotype, indicating a single strain. All of the cultures harbored the virulence genes involved in the different stages of the infection. Surprisingly, the actA gene, which is involved in actin-dependent intracellular motility, displayed a $105 \mathrm{bp}$ deletion. Others have reported a decrease in lethality in mice and cell-to-cell spreading in plaque formation assays of serotype $4 \mathrm{~b}$ strains carrying a similar deletion ${ }^{29}$. A substitution of alanine for proline at position 267 in the actA gene, or the absence of other genes, such as in/C and in/J, may be responsible for the reduced intracellular propagation capacity $^{30}$. However, the ability to spread to other cells and lethality in mice were not significantly reduced by the same $105 \mathrm{bp}$ deletion in the actA gene in serotype $1 / 2 b^{31}$. In our study, in spite of the $105 \mathrm{bp}$ deletion in the actA gene, the strain remained pathogenic and capable of invading the blood stream. It is possible that other virulence-related genes are involved, or that the act $A$ gene is not needed for infection in highly susceptible individuals.

L. monocytogenes endocarditis is rather infrequent, with barely over 70 cases published in the world ${ }^{32}$. Individuals with a history of rheumatic heart disease, hypertrophic cardiomyopathy, mitral valve prolapse or ischemic cardiomyopathy are particularly susceptible ${ }^{4,32}$. The average age of $L$. monocytogenes endocarditis patients increased from 47.1 years during the period from 1955 to 1984 to 65.5 years from 1985 to $2000^{4}$. The patient from our study was the youngest (28 years) among those patients published literature available.

\section{CONCLUSION}

Although uncommon in our region, L. monocytogenes infection should always be considered in the endocarditis differential diagnosis due to its high pathogenicity and broad environmental distribution, which may increase the frequency of contamination by this organism.

\section{ACKNOWLEDGEMENTS}

To Dr Ernesto Hofer and Dr Deyse Christina Vallim from the Laboratório de Zoonoses Bacterianas, Instituto Oswaldo Cruz/FIOCRUZ, Rio de Janeiro, RJ, Brazil for their comments and suggestions.

\section{REFERENCES}

1. Vázquez-Boland JA, Kuhn M, Berche P, Chakraborty $T$, DomínguezBernal G, Goebel W et al. Listeria pathogenesis and molecular virulence determinants. Clin Microbiol Rev [Internet]. 2001 [cited 2013 Jan 10]; 14(3):584-640. Available from: http://www.ncbi.nlm.nih.gov/ pmc/articles/PMC88991 or http://cmr.asm.org/content/14/3/584. long. Review. PubMed PMID: 11432815; PubMed Central PMCID: PMC88991.

2. Allenberger $F$, Wagner M. Listeriosis: a resurgent foodborne infection. Clin Microbiol Infect. 2009; 16(1):16-23. doi: http://dx.doi.org/ 10.1111/j.1469-0691.2009.03109.x/abstract. Review. PubMed PMID: 20002687.

3. Dias V, Cabral S, Anjo D, Vieira M, Antunes N, Carvalheiras G. Successful management of Listeria monocytogenes pericarditis: case report and review of the literature. Acta Cardiol. 2011 Aug; 66(4):537-8. Review. PubMed PMID: 21894816.
4. Fernández Guerrero ML, Rivas $P$, Rábago $R$, Núñez $A$, de Górgolas M, Martinell J. Prosthetic valve endocarditis due to Listeria monocytogenes. Report of two cases and reviews. Int J Infect Dis. 2004 Mar; 8(2):97-102. Review. PubMed PMID: 14732327.

5. Delvallée M, Ettahar N, Loïez C, Decoene C, Courcol R, Wallet F. An unusual case of fatal pericarditis due to Listeria monocytogenes. Jpn J Infect Dis [Internet]. 2012 Jul [2013 Jan 10]; 65(4):312-4. Available from: https://www.jstage.jst.go.jp/article/yoken/65/4/65_312/_ article. doi: http://dx.doi.org/10.7883/yoken.65.312. Joi: DN/JST. JSTAGE/yoken/65.312. PubMed PMID: 22814153.

6. Summa C, Walker SA. Endocarditis due to Listeria monocytogenes in an academic teaching hospital: case report. Can J Hosp Pharm [Internet]. 2010 Jul [cited 2013 Jan 10]; 63(4):312-4. Available from: http:// www.ncbi.nlm.nih.gov/pmc/articles/PMC2932496. PubMed PMID: 22478994; PubMed Central PMCID: PMC2932496. 
7. Pocar M, Passolunghi D, Moneta A, Donatelli F. Fulminant prosthetic valve endocarditis caused by Listeria monocytogenes. Eur J Cardiothorac Surg [Internet]. 2009 Dec [cited 2013 Jan 10]; 36(6):1077. Available from: http://ejcts.oxfordjournals.org/content/36/6/1077. long. doi: http://dx.doi.org/10.1016/j.ejcts.2009.06.036. Epub 2009 Jul 29. PubMed PMID: 19643625.

8. Pierce D, Calkins BC, Thornton K. Infectious endocarditis: diagnosis and treatment. Am Fam Physician [Internet]. 2012 May 15 [cited 2013 Jan 10]; 85(10):981-6. Available from: http://www.aafp.org/ afp/2012/0515/p981.html. Review. PubMed PMID: 22612050.

9. Makaryus A, Yang R, Cohen R, Rosman D, Mangion J, Kort S. A rare case of Listeria monocytogenes presenting as prosthetic valve bacterial andocarditis and aortic root abscess. Echocardiography. 2004 Jul; 21(5):423-7. doi: http://dx.doi.org/10.1111/j.07422822.2004.03093.x. PubMed PMID: 15209721.

10. Rocourt J, Schrettenbrunner A, Seeliger HPR. Differénciation biochimique des groupes génomiques des Listeria monocytogenes (sensu lato). Ann Microbiol (Inst Pasteur) 1983 Jan-Feb; 134A(1):6571. PubMed PMID: 6405670.

11. Clinical and Laboratory Standards Institute - CLSI (US). Performance Standards for Antimicrobial Disk and Dilution Susceptibility Tests for Bacteria Isolated From Animals. Approved Standard. 3rd ed. Wayne (PA): Clinical and Laboratory Standards Institute; 2008. M31-A3.28.

12. Soussy CJ, Ckuzel R, Courvalin P. Comité de I' Antibiogramme de la Société Française de Microbiologie. Definition and Determination of in vitro Antibiotic Susceptibility Breakpoints for Bacteria in France. Eur J Clin Microbiol Infect Dis. 1994 Mar; 13(3):238-46. PubMed PMID: 8050437.

13. Ausubel FM, Brent R, Kingston RE, Moore DD, Seidman JG, Smith JA, Struhl K. Phenol/SDS method for plant RNA preparation. In: Ausubel FM, Brent R, Kingston RE, Moore DD, Seidman JG, Smith JA, Struhl $\mathrm{K}$, editors. Current Protocol in Molecular Biology. New York: Wiley; 1987. Unit 4.3.1-4.3.4.

14. Hudson JA, Lake RJ, Savill MG, Scholes P, McCormick RE. Rapid detection of Listeria monocytogenes in ham samples using immunomagnetic separation followed by polymerase chain reaction. J Appl Microbiol. 2001 Apr; 90(4):614-21. doi: http://dx.doi. org/10.1046/j.1365-2672.2001.01287.x. PubMed PMID: 11309074.

15. Chen Y, Knabel SJ. Multiplex PCR for simultaneous detection of bacteria of the genus Listeria, Listeria monocytogenes, and major serotypes and epidemic clones of L. monocytogenes. Appl Environ Microbiol [Internet]. 2007 Oct [cited 2013 Jan 10]; 73(19):6299304. Available from: http://aem.asm.org/content/73/19/6299. long or http://www.ncbi.nlm.nih.gov/pmc/articles/PMC2075000. doi: http://dx.doi.org/10.1128/AEM.00961-07. PubMed PMID: 17693562; PubMed Central PMCID: PMC2075000.

16. Borucki MK, Call DR. Listeria monocytogenes serotype identification by PCR. J Clin Microbiol [Internet]. 2003 Dec [cited 2013 Jan 10]; 41(12):5537-40. Available from: http://jcm.asm. org/content/41/12/5537.long or http://www.ncbi.nlm.nih. gov/pmc/articles/PMC309009. doi: http://dx.doi.org/10.1128/ JCM.41.12.5537-5540.2003. PubMed PMID: 14662936; PubMed CentralPMCID: PMC309009.

17. Doumith M, Buchrieser C, Glaser P, Jacquet C, Martin P. Differentiation of the major Listeria monocytogenes serovars by multiplex PCR. J Clin Microbiol [Internet]. 2004 Aug [cited 2013 Jan 10]; 42(8):381922. Available from: http://jcm.asm.org/content/42/8/3819.long or http://www.ncbi.nlm.nih.gov/pmc/articles/PMC497638. PubMed PMID: 15297538; PubMed Central PMCID: PMC497638.
18. Ingianni A, Floris $M$, Palomba $P$, Madeddu MA, Quartuccio $M$, Pompei R. Rapid detection of Listeria monocytogenes in foods, by a combination of PCR and DNA probe. Mol Cell Probes. 2001 Oct; 15(5):275-80. PubMed PMID: 11735299.

19. Johnson J, Jinneman K, Stelma G, Smith BG, Lye D, Messer J et al. Natural atypical Listeria innocua strains with Listeria monocytogenes pathogenicity island 1 genes. Appl Environ Microbiol [Internet]. 2004 Jul [cited 2013 Jan 10]; 70(7):4256-66. Available from: http:// aem.asm.org/content/70/7/4256.long or http://www.ncbi.nlm.nih. gov/pmc/articles/PMC444784. PubMed PMID: 15240309; PubMed Central PMCID: PMC444784.

20. Liu D, Lawrence ML, Austin FW, Ainsworth AJ. A multiplex PCR for species-and virulence-specific determination of Listeria monocytogenes. J Microbiol Methods. 2007 Nov; 71(2):133-40. Epub 2007 Aug 28. PubMed PMID: 17884210.

21. Kaur S, Malik SV, Vaidya VM, Barbuddhe SB. Listeria monocytogenes in spontaneous abortions in humans and its detection by multiplex PCR. J Appl Microbiol. 2007 Nov; 103(5):1889-96. PubMed PMID: 17953598.

22. Wiedmann $M$, Bruce $J L$, Keating $C$, Johnson $A E, M c D o n o u g h ~ P L$, Batt CA. Ribotypes and virulence gene polymorphisms suggest three distinct Listeria monocytogenes lineages with differences in pathogenic potential. Infect Immun [Internet]. $1997 \mathrm{Jul}$ [cited 2013 Jan 10]; 65(7):2707-16. Available from: http://iai.asm.org/ content/65/7/2707.long or http://www.ncbi.nlm.nih.gov/pmc/ articles/PMC175382. PubMed PMID: 9199440; PubMed Central PMCID: PMC175382.

23. Tamura K, Dudley J, Nei M, Kumar S. MEGA 4: Molecular evolutionary genetics analysis (MEGA) software version 4.0. Mol Biol Evol [Internet]. 2007 Aug [cited 2013 Jan 10]; 24(8):1596-9. Available from: http://mbe.oxfordjournals.org/content/24/8/1596.long. doi: http://dx.doi.org/10.1093/molbev/msm092. Epub 2007 May 7. PubMed PMID: 17488738.

24. Chun J, Huq A, Colwell RR. Analysis of 16S-23S rRNA intergenic spacer regions of Vibrio cholerae and Vibrio mimicus. Appl Environ Microbiol [Internet]. 1999 May [cited 2013 Jan 10]; 65(5):2202-08. Available from: http://aem.asm.org/content/65/5/2202.long or http://www.ncbi.nlm.nih.gov/pmc/articles/PMC91317. PubMed PMID: 10224020; PubMed Central PMICID: PMC91317.

25. Cruz $C D$, Martinez $M B$, Destro MT. Listeria monocytogenes: an infectious agent scarcely known in Brazil. Alim Nutr. 2008 Apr-Jun; 19(2):195-206.

26. Charpentier E, Courvalin P. Antibiotic resistance in Listeria spp. Antimicrob Agents Chemother [Internet]. 1999 [cited 2013 Jan 10]; 43(9):2103-08. Available from: http://aac.asm.org/ content/43/9/2103.long or http://www.ncbi.nlm.nih.gov/pmc/ articles/PMC89430. Review. PubMed PMID: 10471548; PubMed Central PMCID: PMC89430.

27. Poroś-Głuchowska J, Markiewicz Z. Antimicrobial resistance of Listeria monocytogenes. Acta Microbiol Pol. 2003; 52(2):113-29. Review. PubMed PMID: 14594399.

28. Aureli P, Ferrini AM, Mannoni V, Hodzic S, Wedell-Weergaard C, Oliva B. Susceptibility of Listeria monocytogenes isolated from food in Italy to antibiotics. Int J Food Microbiol. 2003 Jun 25; 83(3):325-30. PubMed PMID: 12745237.

29. Chakraborty T, Ebel F, Wehland J, Dufrenne J, Notermans S. Naturally occurring virulence-attenuated isolates of Listeria monocytogenes capable of inducing long term protection against infection by virulent strains of homologous and heterologous serotypes. FEMS Immunol Med Microbiol. 1994 Nov; 10(1):1-9. PubMed PMID: 7874073. 
30. Geese M, Loureiro JJ, Bear JE, Wehland J, Gertler FB, Sechi AS. Contribution of Ena/VASP proteins to intracellular motility of Listeria requires phosphorylation and proline-rich core but not F-actin binding or multimerization. Mol Biol Cell [Internet]. 2002 Jul [cited 2013 Jan 10]; 13(7):2383-96. Available from: http://www.molbiolcell. org/content/13/7/2383.long or http://www.ncbi.nlm.nih.gov/ pmc/articles/PMC117321/. doi: http://dx.doi.org/10.1091/mbc. E02-01-0058. PubMed PMID: 12134077; PubMed Central PMCID: PMC117321.
31. Chen J, Luo X, Jiang L, Jin P, Wei W, Liu D, Fang W. Molecular characteristics and virulence potential of Listeria monocytogenes isolates from Chinese food systems. Food Microbiol. 2009 Feb; 26(1):103-11. doi: http://dx.doi.org/10.1016/j.fm.2008.08.003. Epub 2008 Oct 18. PubMed PMID: 19028313.

32. Antolín J, Gutierrez A, Segoviano R, López R, Ciguenza R. Endocarditis due to Listeria: Description of two cases and review of the literature. Eur J Intern Med. 2008 Jun; 19(4):295-6. doi: http://dx.doi. org/10.1016/j.ejim.2007.06.020. Epub 2008 Jan 30. PubMed PMID: 18471682. 